\title{
The impact of foreign real estate investment on land prices: evidence from Mauritius
}

Article

Accepted Version

Brooks, C. (2017) The impact of foreign real estate investment on land prices: evidence from Mauritius. Review of

Development Economics, 21 (4). e131-e146. ISSN 1467-9361 doi: https://doi.org/10.1111/rode.12316 Available at https://centaur.reading.ac.uk/69259/

It is advisable to refer to the publisher's version if you intend to cite from the work. See Guidance on citing.

To link to this article DOI: http://dx.doi.org/10.1111/rode.12316

Publisher: Wiley

All outputs in CentAUR are protected by Intellectual Property Rights law, including copyright law. Copyright and IPR is retained by the creators or other copyright holders. Terms and conditions for use of this material are defined in the End User Agreement.

www.reading.ac.uk/centaur 
Central Archive at the University of Reading

Reading's research outputs online 


\title{
The Impact of Foreign Real Estate Investment on Land Prices: Evidence from Mauritius
}

\author{
Chris Brooks, ICMA Centre, University of Reading* \\ Matthew Lamport, University of Mauritius \\ Kesseven Padachi, University of Technology, Mauritius \\ Raja Vinesh Sannassee, University of Mauritius \\ Keshav Seetah, University of Mauritius \\ Boopen Seetanah, University of Mauritius
}

February 2017

\begin{abstract}
This paper examines the impact of foreign real estate on land prices in Mauritius. Using a panel dataset comprising price, quantity and other information for a variety of luxury villas and apartments, we show that the price of land paid by locals has been pushed up by a modest 4$22 \%$ in total as a result of these developments. We also examine the determinants of the prices of the dwellings in these schemes, finding that they are strongly related to the sizes of the plots, whether they have ocean views and the desirability of the region in which they are sited, although there remains considerable unexplained heterogeneity.
\end{abstract}

Keywords: real estate investment, foreign direct investment, foreign land ownership, Mauritius JEL Classifications: F21, O18, Q15, R31

* Corresponding author: Chris Brooks, ICMA Centre, University of Reading, Whiteknights, Reading RG6 6BA, UK; e-mail: C.Brooks@reading.ac.uk

Acknowledgements: The authors are grateful for comments from two anonymous referees on a previous version of this paper. 


\section{Introduction}

A great deal has been written in the Western media and by international bodies such as the United Nations on the issue of foreign real estate investment (FREI) - that is, foreign purchases of land - in Africa. Up to $90 \%$ of land does not have a titled owner in sub-Saharan Africa and this often makes it easier for land to be sold to foreign investors. ${ }^{1} \mathrm{~A}$ report by the Oakland Institute, a US research unit, suggested that hedge funds had purchased huge areas of African land which were taken from millions of small planters and which were then used to grow biofuels or cut flowers for export. In just over a decade since 2000, an area eight times the size of Britain has been sold or leased to foreigners by the developing world. ${ }^{2}$ To illustrate, in Madagascar alone, almost half of all cultivated land is foreign-owned. ${ }^{3}$ Hundreds of thousands or in some cases millions of hectares of land have allegedly been sold by Kenya, the Democratic Republic of Congo, Ethiopia, South Africa, Liberia, Mali, Angola, Mozambique, Sudan to countries as diverse as Qatar, Egypt, Libya, China and South Korea (details are provided in Martin and Ayalew, 2011; see also Smaller and Mann, 2009). Sub-Saharan Africa has been a particular focus of foreign land purchases since the area of cultivatable land available is larger than elsewhere and because of a perception that the land and local labour are both cheap (Abebe, 2012). ${ }^{4}$ Although the amount of available land in Africa is vast, the distribution of purchases by foreign firms is concentrated within a small number of countries (Holmén, 2015). Land in Africa is not only being purchased by foreign firms for agricultural use, to grow biofuels, and to improve the level of food security in those countries, but also to guarantee access to commodity resources (including precious and non-precious metals and especially oil that are needed for thirsty production processes).

Much of this writing in the Western media is highly politicised, with talk of "land grabs," where local people and businesses are argued to have been crowded out or even evicted, their land commandeered against their will or without adequate compensation. Uncomfortable links are suggested with Western countries' colonial pasts (Zoomers, 2010). The rural poor are likely to be most affected, since their land is in many cases their only productive asset and their main or only source of food (Abebe, 2012, p.877) and they typically in poor negotiating positions with large multinationals (Li, 2011). Yet when organised in an appropriate manner, foreign land purchases can

\footnotetext{
${ }^{1}$ Source: "How African governments allow farmers to be pushed off their land", The Guardian, 2 March 2012.

${ }^{2}$ See, for example, "Down on the Farm. Wall Street: America's New Farmer" 2014, Oakland Institute,

http://www.oaklandinstitute.org/down-on-the-farm ; see also Cotula et al. (2009) and Cuffaro and Hallam (2011).

${ }^{3}$ Source: GTZ report, FDI in Land in Developing Countries, 2009.

${ }^{4}$ Arezki et al. (2011, p. 8) suggest that around 200 million hectares of cultivatable land may be available in SubSaharan Africa.
} 
be highly beneficial to the local economy, bringing in much needed investment, technology transfer, enhanced knowledge and skills, and creating jobs. Ogundipe and Egbetokun (2014) show that an increase in the area of land under cultivation can lead to a growth in income levels for both farmers and non-farmers. Land can also be diverted to more productive uses in some cases, thus increasing its productivity. Often the land is sold to foreign firms with the proviso that the firm uses their expertise and contacts to improve the local infrastructure such drainage and sanitation, an electricity grid, roads and bridges or even a school (Holmén, 2015) and valuable additional foreign exchange and/or tax receipts for the government may be created (Arezki et al., 2011).

Yet the dangers are equally clear: land sold under-value (see Holmén, 2015, p. 467) and turned over to new uses may result in food and/or water shortages so that foreign investors merely substitute food insecurities in their home countries for a similar situation in Africa. This may be coupled with a fall in job opportunities for locals since skilled labour is not available in-country and is therefore temporarily imported; an increase in the price of land that local residents would otherwise pay may also result. Foreign multinationals are often given generous tax breaks so that little additional revenue may be received by the government. A sudden influx of 'easy money' may also encourage corruption (Bhattacharyaa and Hodler, 2010).

This paper is, to our knowledge, one of the first and only quantitative studies of the impact of overseas purchases and on land prices in a foreign country. ${ }^{5}$ The Mauritian context is also somewhat different to those discussed in existing studies since the majority of recent land sales (especially by value) have not been for agricultural or industrial use, but rather to build high quality residential villas with close proximity to the sea specifically for foreign purchase. The core focus of this research is to test whether the impact of foreign purchases of real estate in Mauritius has had an inflationary impact on the price of land. A priori, one might expect that, given a fixed supply of land overall, in regions containing large villa developments there would be a 'trickledown' or 'earthquake'-type effect so that prices of all land will increase to some extent even where it is not linked in terms of usage to or contiguous with, the purchased land. Thus, the expected impact of foreign investment would be to push up the prices of prime land (e.g. in the most desirable locations or with an ocean view) faced by locals, and this in turn could possibly have an effect on the price of not only neighbouring but less desirable land but also farming or industrial land, albeit to a lesser extent. According to this viewpoint, the impact of real estate developments on the prices of land might be more moderate the greater the distance from the real estate development area. It is also possible

\footnotetext{
${ }^{5}$ A study exists which examines this broad question, but it is focused on the determinants of FREI rather than its impact (see Rodriguez and Bustillo, 2010).
} 
that the impact in Mauritius, a small island, could be more severe than in other African countries since the amount of prime beachfront land available is in very small supply and a large proportion is already taken up by hotels and thus not available to the real estate market.

There is evidence internationally to support the view that this upward pressure on land valuations may occur, with for example farmland prices in Brazil and Poland having jumped by $16 \%$ and $31 \%$ respectively in the year 2007 alone (von Braun and Meinzen-Dick, 2009). Several detailed reports have been written by reputable international bodies on the issue of foreign ownership of land in Africa (for instance refer to GTZ Federal Ministry for Economic Cooperation and Development, Germany (2009) and FAO (2009). These describe the extent of the issue and suggest possible outcomes - both good and bad - for the host countries concerned. But the documents cannot provide any concrete evidence of the effects that foreign land purchases are having, in part because of a lack of data and perhaps because of the reluctance on the part of researchers to formulate the research questions in an objective, transparent and apolitical manner. So, perhaps unsurprisingly, we face a situation where there has been no formal quantitative analysis of these issues and existing research is at best purely descriptive, anecdotal and at worst speculative and biased in its conclusions and policy implications.

Mauritius presents a good case study as it has also been opening itself to foreign land buyers, mostly geared towards the acquisition of residential properties. The Mauritian government developed the Integrated Resort Scheme (IRS) and Real Estate Scheme (RES), attempting to capitalize on the fact that travelers may seek to prolong their feeling of enjoyment arising from the good times they experienced on their holiday by taking up permanency of residence on Mauritius. Under the above schemes, luxury villas and apartments, built on prime land can be acquired freehold by foreigners who de facto receive a residence permit on the acquisition of a residential unit worth USD 500,000. Luxury villas put on the market so far have proved very appealing for those investing in a second home, with overnight reservations and sales. We are able to exploit a unique, hand-collected database on IRS/RES, making this study the first of its kind.

Figures from the Bank of Mauritius (BOM) show that foreign direct investment (FDI) amounted to over Rs 5 billion at the first semester 2014, which represented an increase of $8.7 \%$ over the corresponding period in 2013. As such, the real estate sector contributed to more than $50 \%$ of this total FDI, resulting in investments in IRS projects of Rs 2.9 billion. Since 2006, the IRS / RES segment attracted nearly 19.5 billion rupees of investment. More broadly, the latest official figures showed that the housing sector attracted almost $60 \%$ of foreign direct investment in 2013 . Indeed, since 
2006, real estate has constituted the lion's share of investment from abroad, with an average of $40 \%$ annually. Against this backdrop, the construction sector has become indebted to the tune of Rs 75 billion as of 28 February 2014 (BOM, 2014), driven by a significant increase in the number of IRS/RES dwellings constructed. Official figures reveal that the total number IRS / RES residential units sold (as at December 2013) amounted to 1122 . The volatility of the Mauritian rupee against the US dollar and other major currencies may provide some limit on the attractiveness of investing in Mauritius for international buyers as hedging is difficult and costly.

To investigate the effect of foreign land acquisition on local land prices, this study adopts pooled and panel regression approaches over the period 2006-2013, with as large a sample as possible of IRS and RES constructions. Our objectives are first, to formally investigate whether foreign ownership of luxury properties does put upward pressure on the prices that locals must pay for land in neighbouring areas, and second, to determine the factors that affect the prices of the villas in these developments. The remainder of the paper is structured as follows: Section 2 provides a brief literature review on the impact of foreign real estate investment on local land prices. Section 3 dwells on the evolution of FREI in Mauritius while Section 4 discusses the methodology and analyses the empirical results. Section 5 concludes the study.

\section{Related Literature}

The existing economic literature suggests that FDI in real estate (like FDI in other services) will assist a host country's economic development by injecting financial resources, the provision of services in terms of supply, cost, quality and variety, introducing additional competition, generating employment and bringing technology (Arnold et al, 2006; UNCTAD, 2004; Golub, 2009). There have been a number of studies that provide appealing insights on the effects of capital inflows and asset price appreciations. For instance, Bo and Bo (2007) used an Error Correction Model (ECM) and Granger causality test to examine the relationship between house prices and international capital flows over the period of 1998 to 2006 in China and concluded that in the short run, the increase of housing prices fostered inflows of foreign capital; in the long run, foreign capital helped to boost the rise of house prices. Kim and Yang (2011) empirically examined the effects of capital inflows on asset prices (including stock, land and nominal and real exchange rates) among emerging Asian economies (South Korea, Indonesia, Malaysia, Philippines and Thailand). Their empirical results suggested that capital inflows contributed to asset price appreciation in emerging Asian economies. Salami et al. (2010) concluded that massive capital inflows led to credit and real estate booms during 2000-2007 
in Estonia because this external financing fuelled rapid domestic credit growth, mainly to households, for real estate purchases in the form of foreign currency loans. Kim and Yang (2009) empirically investigated whether capital flows induced domestic asset price appreciations in Korea. They found that capital inflow shocks caused stock prices to increase. However, their results suggested that the influence of capital inflow shocks was moderate in other sections of economy (e.g. land prices, nominal and real exchange rates and liquidity).

Calvo et al. (1996) argued that rising capital inflows should be associated with higher equity and real estate prices in most capital-importing countries. Likewise, Guerra de Luna (1997) noted that episodes of large capital inflows have often been associated with growing imbalances, such as an increase in real estate prices and a real currency appreciation. Downs (2007) also concluded that a surge in capital flows was a crucial factor influencing the rise in global commercial real estate prices during the 2002 to 2007 period. Copeland (1991) pointed out that foreign capital inflow increases land and housing costs, making local businesses (especially small and medium-sized enterprises that often do not own real property) very difficult to run in a profitable way because of high rental costs. In his study on stock price bubbles for the case of Malaysia and Singapore, Rangel (2010) found that real GDP growth and capital flows were consistently significant explanatory variables. Using a sample of 1400 properties over the period 1990 to 1995, Redman and Gullett (1998) examined the impact of foreign investor purchases and sales of commercial properties on property prices in the United States. By applying multiple regression analysis, they found that the existence of foreign investors increased demand adequately to raise property prices.

Guo and Huang (2010) studied the extent of the impact from hot money flows (speculative capital inflow) on the fluctuations of China's real estate market and stock market. The results indicated that hot money flows had driven up property prices as well as contributed to accelerating volatilities in both markets due to its size and the short term investment horizon of such investors. By applying a panel data model, Cheng et al. (2006) found that hot money significantly impacted on real estate prices in China. Jansen (2003) examined the effects of private financial capital inflows in Thailand in the pre-crisis period, finding that private capital inflows were associated with higher asset prices, lower lending rates, surges in bank lending and domestic spending driven by higher investment, higher output, modest inflation, and modest real exchange rate appreciation. Zheng et al. (2009) showed that home prices in Chinese cities increase in response to FDI inflows. Ben-Yehoshua (2008) argued that strong economic growth and impressive flows of FDI contributed to real estate price increases in the metro cities of China. In a comparable study, Cordero and Paus (2008) noted that 
large amounts of foreign investment in Costa Rica's real estate sector (about 25\% of total FDI inflows) contributed to the development of real estate prices over the 2004-2006 period. Sajor (2003) argued that the unprecedented flow of international portfolio investment in real estate facilitated boom and bust property cycles during the 1980s and 1990s globally. A study by Rajan and Siregar (2002) showed that portfolio capital inflows in East Asia were the main factor explaining the rebound in regional growth rates, surges in equity prices and stabilization of exchange rates during the pre-crisis boom period (between 1990 and 1996). Mihaljek (2005) noted that the increased level of foreign capital into the real estate market would raise the demand for property and consequently this would tend to drive real estate prices up in Croatia (due to the relatively fixed short-run supply of real estate).

However, inconsistent with the above studies, Chan (2007) showed that FREI in China was not a cause of high house prices in recent years because FREI was a tiny portion of the total real estate investment in China. By using Chinese panel data of 35 main cities stretching from 1998 to 2007, Yu (2010) found that there was no relationship between FDI (as one of the economic fundamentals) and house prices. He also showed that house prices in China were largely affected by government land policy. Similarly, in their study on the United Kingdom (UK) private commercial real estate market, Ling et al. (2009) found that capital flows were not a prime determinant of price movements.

\section{FREl in Mauritius}

With a current population revolving around 1.3 million inhabitants, Mauritius is recognised to be one of the strongest, most competitive and stable economies in Africa. ${ }^{6}$ According to the 2014 Investment Climate Statement, Mauritius had a Gross Domestic Product (GDP) per capita of over $\$ 8,500$, in 2013 , one of the highest in the African region. Subsequently, this economic situation has geared Mauritius to open its investment borders and to focus assiduously on foreign ventures. As stated in the World Bank Report "Investing across Borders" (2010), Mauritius has one of the economies most open to foreign ownership in the world and one of the highest recipients of FDI per capita. This quantifies the surge in the Mauritian real estate sector during the past decades.

\footnotetext{
${ }^{6}$ The World Economic Forum ranked Mauritius first in competitiveness among sub-Saharan African economies in 2014, even above South Africa (see https://www.weforum.org/agenda/2014/09/top-10-competitiveeconomies-sub-saharan-africa).
} 
Some of the crucial factors that drive investors to choose Mauritius as an investment destination include i) Social and Political stability ii) Advantageous tax system (a harmonised 15\% corporate, VAT and income tax) iii) Resilient and diversified economy which upholds a good standard of living iv) Tourism is considered a key pillar of the economy and supported strongly by the Government. The higher are tourist arrivals, the better the hotel sector will perform, thus properties such as hotels and condominiums constitute profitable investments with high returns on investment v) Legal provisions to facilitate investment in the country (business-friendly environment) and vi) Modern and reliable infrastructure.

The Mauritian real estate sector comprises of two components, namely: commercial and residential property. To enable foreign investment in real estate, the Mauritian government instituted the Real Estate Development Scheme - the latter assists a non-citizen to acquire and be the owner of immovable property such as apartments, luxurious villas, or hotel rooms/suites or to participate financially in any hotel projects formally approved by the Board of Investment (BOI). As such, real estate investors and property developers have as prospects to develop under two specific schemesthe Integrated Resort Scheme (IRS) and Real Estate Scheme (RES). The IRS was launched in 2002 by the $\mathrm{BOI}$ in Mauritius with the aim to create a boom in the tourist industry by allowing affluent foreign investors to buy properties with a minimum price of USD500,000 and subsequently obtain residency status along with numerous tax incentives. However, the $\mathrm{BOI}$ closely scrutinises these resorts and approves only those with development finance accompanied by appropriate low density and high quality, well specified villas.

It is important to note that in order to prevent over-development on the island, a maximum of 5,000 of such villas was permitted to be constructed and stringent planning and regulation were also put in place. This led to the first IRS scheme hitting the market only in 2005. One of the first IRS developments was Tamarina, which turned out to be a huge success given the strong demand from South Africans as there was an agreement between Mauritius and South Africa which meant that citizens of the latter could advantageously invest a considerable amount of money in the former. Many South Africans view Mauritius as a safe haven for investment, even more so given the relatively volatile and turbulent political and economic conditions prevailing in their home country and as a result villas in Tamarina were completely sold out by 2008 . Some buyers did use such an unequivocal demand for such villas to undertake speculative acquisition which led indeed to 
substantial windfall gains, with some villas being sold in the secondary market for nearly twice the price for which they were purchased. ${ }^{7}$

Following the success of the IRS in attracting foreign investment among high net worth individuals, RES was introduced in 2007 to enable foreign home ownership on the island to be more affordable to a broader audience. In comparison to an IRS, a RES has no minimum price and may include apartments and the density of construction may also be higher.

\section{Trends in the Mauritian Real Estate Sector}

Recent reports published by African Economic Outlook lay much emphasis on how the Mauritian real estate sector has been proficient in facing fluctuating global financial conditions. Such an achievement is mainly ascribed to the 'planned' construction boom, ${ }^{8}$ the prevailing political stability, the reliable infrastructure and the surge in the luxury tourism market. Due to such stimulus packages, Mauritius is continuing to become more and more appealing to foreign high net worth individuals looking for alternative places of residence and professionals from abroad working in high end business sectors. This may be the underlying motive as to why the growing number of sugar estates and other dwindling industries are shifting from their core activities into residential developments and/or construction of shopping malls.

In its 2013's report, the BOI recorded that the real estate and construction sectors had gained prominence in the Mauritian economic landscape since, accounting for more than $40 \%$ of the total FDI (as shown in Figure 1). Likewise, these sectors are considered as being key features of the investment strategies engineered by the tourist promoters and the government itself. Land prices as well as those of completed dwellings have increased significantly over the last decade or so, albeit such increases varying between regions and areas (see Figure 2). The graph clearly shows a significant land price hikes over the last 13 years for all regions in Mauritius although, such price increases is more pronounced for the S.W Tamarina/West Coast. Plausible explanations explaining such an increase in prices include amongst others the proximity of these plots of land to IRS and ERS developments and the increasing demand for gated community by local people.

\footnotetext{
${ }^{7}$ There have been also other IRS developments such as Anahita in the east and Villas Valriche in the southwest of the island which have been very successful such that villas were sold out at the initial stage and early buyers enjoyed significant appreciation in the value of their villas.

${ }^{8}$ This construction boom is coined as 'planned' since the government has increased its incentives to market Mauritius as a Real Estate investment destination.
} 
Such an upward spiral in prices may, to a large extent, be related to the very small size of the island, and land being a scarce resource. Unfortunately, the existing literature is devoid of any study providing any plausible explanation as to why such an increase in land prices has been so pronounced over the last ten years in particular. Given the above, we contend that one of the underlying reasons for such a price hike may be related to the promulgation of the IRS and RES schemes by the Government in the early years of the new millennium which in turn led to a jump in demand for land in certain prime locations. In addition, the provision of high class leisure and commercial facilities in close proximity to such IRS and RES could only have served to enhance the land value. These facilities include, although are not limited to, golf courses, shopping malls, restaurants and 'wellness' centres. We further contend that such an upward price spiral may also be the result of the introduction of 'Work \& Live in Mauritius' scheme which has led to an influx of retired non-residents and foreign skilled workers boasting much higher purchasing power than that of the local population.

< Figure 1 about here >

\section{Methodology and Analysis}

As stated above, to investigate the effect of foreign land acquisition on local land prices, this study adopts an econometric analysis (a pooled regression) over the period 2000-2013. We examine as large a sample as possible of IRS and RES developments over the period 2000-2013, although the majority of such schemes operated towards the end of this period. We classify the developments by region and we then sum all of the sales of villas or apartments in a particular scheme in a particular region for each year. Table 1 provides a summary table of the main foreign residential estate investments which were used in our sampling and for which data were made available. Given the small size of the Mauritian economy and of the prime seafront land available, the figures in the table demonstrate the scale of developments, with several projects involving more than 100 constructed units selling at an average price of over a million US dollars.

$<$ Table 1 about here >

\section{Does Foreign Real Estate Investment Affect Local Land Prices}

The dependent variable in this first set of regressions is the annual percentage change in the price of the local land. We regress this variable on a constant and the single explanatory variable is the total value of all the IRS developments sold in that region in that year. We also have information on the total size of the IRS developments in terms of squared metres but it was not possible to 
simultaneously include this variable since it is too highly correlated with the value (as one would expect). We also considered the use of an ocean-view dummy variable (taking the value one if the development directly faces the sea and zero otherwise) but this variable also presented some multicollinearity problems due to the small number of separate developments.

We experimented with a fixed effects panel regression, including either region or time fixed effects (or both), but these fixed effects were never statistically significant according to a redundancy test and we therefore exclude them and instead opted for a pooled regression. The limited sample size, both cross-sectional and in terms of the number of years, is a severe limitation on the sophistication of the models we are able to employ. We have a total of 48 region-years. We allow for heteroscedasticity in the errors using White's correction. The models' parameter estimates are presented in Table 2 with t-ratios in the third and fifth columns.

$<$ Table 2 about here>

As the results in Table 2 show, the key variable is significant at the $10 \%$ level, suggesting that increases in the amount of investment in IRS/RES schemes is mildly and positively related to the price of local land. The $R^{2}$ is not very high but acceptable, and shows there is also a lot of other variability in the price changes not related to the IRS/RES developments. The slope coefficient is very small but this is due to the scaling of the dependent and independent variables - the dependent variable is in percentage terms while the independent variable is in rupees. We can therefore state that for every Rs100million of IRS/RES sold, the local land price will increase by $0.3 \%$, which is a small but non-trivial effect. If we extrapolate this to the total value of all RES/IRS developments sold for each region, the price effects are between $4 \%$ and $22 \%$, depending on the region.

\section{What Factors Affect the Prices Charged for Integrated Resort Schemes?}

We established in the previous section that foreign investment in prime seaside properties in Mauritius has a modest and marginally statistically significant effect on the prices of land paid by local residents. Using the same set of data, it is of interest to examine the factors that affect the prices of the IRS villas themselves using a hedonic regression approach. We therefore now consider this using the entire sample of villas as individual entities. We can no longer focus on changes in prices but now examine the levels, i.e. the dependent variable is the price of a specific villa, since we do not have repeated sales information and each villa is sold only once. The explanatory variables are the plot size (in squared metres), a 0-1 dummy variable for whether the villas are ocean side (as 
opposed to being a short walk from the sea), the price of local land (in rupees per toise) ${ }^{9}$ and a set of eight separate project/regional dummies ( 1 =West/Albion; 2 = South East/Anahita; 3 = South West $/$ Bel Riviere; 4 = South West/Dolphine Coast; 5 = North East/Haute Rive; 6 = South West $/$ Matala; 7 = South West / Wolmar; 8 = South / Bel Ombre). In total, there are 610 observations spread over the eight regions and spanning a total of nine years from 2005 to 2013 with the model estimated using ordinary least squares. The sample is very unbalanced over time since most developments only offer villas for sale for about three to four years typically with some developments coming on stream early (e.g., Anahita, Tamarina) and others not coming to market until towards the end of our sample period (e.g., Dolphin Coast, Haute Rive).

The results are presented in Table 3 - the left-hand panel also includes dummy variables for the year of sale to capture any general upward trend in real estate prices over time while the right-hand panel excludes these. The dummy variables for 2005 and Region 1 are excluded from the regression and these therefore become the reference categories. It is evident from the final two columns of the left-hand panel of Table 3 that none of the year dummies are even close to statistical significance. Therefore, there is no evidence of an upward drift in prices over the sample period and our ensuing discussion therefore focuses on the parameter estimates presented in the right-hand panel of the table where the year dummies are excluded.

$<$ Table 3 about here >

It is evident that several factors significantly affect the price of IRS/RES villas in Mauritius, and all of the variables we employ in the regressions have the correct sign and are of meaningful magnitudes. Plot size has a highly significant ( $p$-value: 0.000 ) positive effect on prices, with every additional square metre of floor space adding on average approximately Rs30,000 to the price. ${ }^{10}$ The residencies with an ocean view are significantly more expensive, both in statistical (although only at the $10 \%$ level) and in economic terms. Such a view commands an additional Rs $32 \mathrm{~m}$ on the price, all else equal. ${ }^{11}$ Every increase of Rs1000 per toise in the price of local property occurs with an increase in the price of an IRS/RES villa in the same region of Rs10.5 million, which is highly statistically significant.

\footnotetext{
${ }^{9} \mathrm{~A}$ toise is a locally used measurement of area which is equivalent to 3.8 square metres.

${ }^{10}$ The prices of land for sale aimed at local residents is naturally priced in Mauritian currency. As at April 2016, there are approximately 50 MUR per GBP and 35.3 USD.

${ }^{11}$ This is perhaps a surprisingly large figure but we note, of course, that the ocean view properties may also be better specified - for example, having additional amenities, more bathrooms, more expensive appliances, but we are not able to capture any specific features apart from floor space.
} 
There are also statistically significant variations in the typical villa prices for each project development. Measured relative to the omitted dummy variable category (project/region 1: Albion), prices on average, and holding all other factors constant, are significantly cheaper for developments 3 (Belle Riviere), 4 (Dolphin Coast) and 7 (Tamarina), while they are more expensive in 2 (Anahita), 5 (Haute Rive), 6 (Matala), and 8 (Bel Ombre), although none of the latter are significantly so.

Finally, considering the fit of the model as a whole to the data, we note that the $R^{2}$ value is within the expected range for an essentially pooled regression at 0.18 . This suggests, however, that a considerable proportion of the variation in prices from one villa to another has not been explained by the model. These omitted factors are likely to relate to unmeasured characteristics of both the villas themselves (e.g., quality of internal finishing, size of external space and proximity to neighbouring villas) or of the local amenities (e.g., on-site spa or sports facilities, mountain views, shopping centres). In this table we also present the results from three diagnostic tests for model adequacy. The Durbin-Watson and Breusch-Pagan-Godfrey tests indicate that there is no issue with either residual autocorrelation or heteroscedasticity respectively. The Jarque-Bera test indicates that the residuals are not normally distributed, but by appealing to the central limit theorem, we argue that this is not an issue due to the large sample size that we have available.

\section{Conclusions}

The primary aim of this paper was to investigate the effect of foreign purchases of real estate in Mauritius on the prices that local people pay for land, exploiting a unique, hand-collected dataset of prices and characteristics of high quality villas and apartments. Mauritius poses as a good case study as it has been opening itself to foreign buyers particularly in the acquisition of residential properties through the Integrated Resort and Real Estate Schemes. To analyse the effect of FREI on local land prices, this study examines a sample of IRS and RES developments over the period 2000-2013. Using a pooled regression, the results confirm that increases in the amount of investment in IRS/RES schemes are positively related to the price (although to a relatively low extent) of local land. In fact, it was found that, based on the sample and data available, for every Rs100million of IRS/RES sold, the local land price is likely to increase by approximately $0.3 \%$. Extrapolation to the total value of all RES/IRS developments sold for each region would imply that the price effects are between $4 \%$ and $22 \%$, depending on the region.

While the specific affect attributable to foreign real estate investment is modest, there may nonetheless be some potentially less desirable repercussions. First and foremost, increasingly national residents are being priced out of any opportunity of acquiring land in prime locations and 
even the more affluent locals are pushed away from their desired places of residence. This impact may in turn negatively impact on the way local residents perceive foreign nationals. To make matters worse, the anticipated spill-over benefits from such IRS and RES schemes in terms of increased demand for high end goods and personal services have not materialised given that most of the foreign owners only visit the island for a short period of time and therefore contribute little to the on-going growth of the local economy. It would appear to be the case that the underlying motivation for acquiring such RES and IRS in many instances was to benefit from owning a holiday home in the short term and then to cash in on its expected future price rise as prime oceanfront land becomes scarcer in the longer term. 


\section{References}

Arezki, R., Deininger, K., and Selod, H. (2011) What Drives the Global "Land Rush"? World Bank Development Research Group Policy Research Working Paper 5864.

Ben-Yehoshua, A. (2008) Foreign direct investment in the Chinese real estate industry, Israeli Chamber of Commerce in Shanghai. Available at: http://www.ischamshanghai.org.

Bhattacharyya, S. and Hodler, R. (2010) Natural Resources, Democracy and Corruption, European Economic Review 54(4), 608-621.

Bo S. and Bo, G., (2007) The Impact of International Capital Flows on Real Estate Markets, Financial and Economic Questions Research, 3, 55-61.

Calvo, G. A., Leiderman, L. and Reinhart, C. M. (1996) Inflows of capital to developing countries in the 1990s, Journal of Economic Perspectives 10(2), 123-139.

Chan, N. (2007) Should foreign real estate investment be controlled in China? Pacific Rim Property Research Journal 13(4), 473-492.

Cheng, L. W., Zhang, T. T. and Sun, W. (2006) The empirical study of the impact of FDI in real estate on price of real estate, Proceedings of International conference on construction \& real estate management, 1 \& 2, 1547-1549.

Copeland, B. (1991) Tourism, welfare, and de-industrialization in a small open economy, Economica 58(232), 515-529.

Cordero, J. and Paus, E. (2008), Foreign investment and economic development in Costa Rica: the unrealized potential, Working Group on Development and Environment in the Americas Discussion paper, 13, 1-27.

Cotula, L., Vermeulen, S., Leonard, R. and Keeley, J. (2009), Land grab or development opportunity? Agricultural investment and international land deals in Africa, IIED/FAO/IFAD, London/Rome. ISBN: 978-1-84369-741-1 
Cuffaro, N. and Hallam, D. (2011) Land Grabbing in Developing Countries: Foreign Investors, Regulation and Codes of Conduct, Electronic copy available at: $\mathrm{http}$ ://ssrn.com/abstract=1744204. Downs, A. (2007) Niagara of Capital: How Global Capital has Transformed Housing and Real Estate Markets Washington, D.C.: The Urban Land Institute.

FAO (2009) Land Grab or Development Opportunity: Agricultural investment and international land deals, in Africa Food and Agriculture Organization of the United Nations, available at http://www.fao.org/3/a-ak241e.pdf.

GTZ Federal Ministry for Economic Cooperation and Development (2009) Foreign Direct Investment (FDI) in Land, in Developing Countries GTZ Federal Ministry for Economic Cooperation and Development, Germany, available at www.giz.de/expertise/.../giz2010-en-foreign-direct-investmentdc.pdf.

Guerra de Luna, A. (1997), "Residential real estate booms, financial deregulation and capital inflows: An international perspective", Mimeo, Banco de Mexico.

Guo, F. and Huang, Y. S. (2010) Does "hot money" drive China's real estate and stock markets? International Review of Economics and Finance, 19(3), 452-466.

Holmén, H. (2015) Is Land Grabbing Always What it is Supposed to be? Large-Scale Land Investments in Sub-Saharan Africa, Development Policy Review 33(4), 457-478.

Jansen, W.J. (2003) What do capital inflows do? Dissecting the transmission mechanism for Thailand, 1980-1996, Journal of Macroeconomics 25(4), 457-480.

Kim, S., and D.Y. Yang (2009) Do Capital Inflows Matter to Asset Prices? The Case of Korea, Asian Economic Journal 23(3), 323-348.

Kim, S. and Yang, D. Y. (2011) Financial and Monetary Cooperation in Asia: Challenges after the Global Financial Crisis, International Economic Journal 25(4), 573-587.

Li, T.M. (2011) Centering Labor in the Land Grab Debate, Journal of Peasant Studies 281-298. 
Ling, D. C. and Marcato, G. and McAllister, P. (2009) Dynamics of asset prices and transaction activity in illiquid markets: The case of private commercial real estate, Journal of Real Estate Finance and Economics, 39(3), 359-383.

Mihaljek, D. (2005) Free movement of capital, the real estate market and tourism: A blessing or a curse for Croatia on its way to the European Union? In: Ott, K. (ed.), Croatian Accession to the European Union: Facing the Challenges of Negotiations, Institute of Public Finance, Volume 3, Pages 185-228.

Ogundipe, A.A. and Egbetokun, S.O. (2014) Does Foreign Land Acquisition Deprive Per Capita Income in Africa? Research in Applied Economics 6(4), 12-34.

Rajan, R. S. and Siregar, R. (2002), "Private capital flows in East Asia: Boom, bust and beyond", In: de Brouwer, G. (ed.), Financial Markets and Policies in East Asia, Routledge Press, Pages 47-81

Rangel, G. J. (2010) Evidence, determinants, and consequences of asset price bubbles: The case of Malaysia and Singapore, Unpublished PhD Dissertation, School of Management, Universiti Sains Malaysia (USM).

Redman, A.L. and Gullett, N.S. (2010) An Empirical Study of the Impact of Foreign Ownership on the Values of US Commercial Properties, Journal of Financial And Strategic Decisions 11(1), 53-60.

Rodríguez, C. and Bustillo, R. (2010) Modelling Foreign Real Estate Investment: The Spanish Case, Journal of Real Estate Finance and Economics 41, 354-367.

Sajor, E. E. (2003), Globalization and the urban property boom in Metro Cebu, Philippines, Development and Change, 34(4), Pages 713-741

Salami, A. Kamara, A.B. and Brixiova, Z. (2010), Smallholder Agriculture in East Africa: Trends, Constraints and Opportunities, African Development Bank Group Working Papers, Number 105.

Smaller, C. and Mann, H. (2009), A thirst for Distant Lands: Foreign Investment in agricultural Land and Water, International Institute for Sustainable Development. 
Von Braun, J. and Meinzen-Dick, R. (2009), "Land Grabbing" by Foreign Investors in Developing Countries: Risks and Opportunities, IFPRI Policy Brief 13.

Yu, H. (2010), China's house price: Affected by economic fundamentals or real estate policy?, Frontiers of Economics in China, Volume 5(1)

Zheng, S., Kahn, M. E. and Liu, H. (2009), Towards a system of open cities in China: Home prices, FDI flows and air quality in 35 major cities, NBER Working Paper, No. 14751.

Zoomers, A. (2010) Globalisation and the Foreignisation of Space: Seven Processes Driving the Current Global Land Grab, Journal of Peasant Studies 37(2), 429-447. 
Table 1: Summary details of FREI included in the sample

\begin{tabular}{|c|c|c|c|c|c|c|c|c|}
\hline Code/Region & Project Name & $\begin{array}{l}\text { Project } \\
\text { location }\end{array}$ & $\begin{array}{l}\text { No. of } \\
\text { Resident } \\
\text { ial Units }\end{array}$ & $\begin{array}{l}\text { Commercial } \\
\text { Components }\end{array}$ & $\begin{array}{l}\text { Land area } \\
\text { (ha) }\end{array}$ & $\begin{array}{c}\text { Plot size } \\
\text { (in square } \\
\text { metres) }\end{array}$ & Proximity to the sea & Selling Price \\
\hline 2 (South East) & Anahita IRS & Beau Champ & 372 & $\begin{array}{c}\text { 18- Hole Golf Course; } 90 \\
\text { room hotel ; club house and } \\
\text { restaurant }\end{array}$ & 214.00 & 63.61-307.1 & Ocean view & USD $714,000-1,426,000$ \\
\hline 7 (South West) & Tamarina Golf Estate & $\begin{array}{c}\text { Wolmar, Chassée } \\
\text { Mamet }\end{array}$ & 119 & $\begin{array}{c}\text { 18-hole golf course; Golf } \\
\text { club house }\end{array}$ & 206.60 & $2927-5264$ & $\begin{array}{c}\text { walking distance from the } \\
\text { sea }\end{array}$ & USD $580,000-3,275,000$ \\
\hline 1 (West) & $\begin{array}{c}\text { Albion Development } \\
\text { Ltd (Club Med) }\end{array}$ & Albion & 40 & Club Med Hotel & 12.70 & $1304-2326$ & Ocean view & Euro $868,000-1,847,250$ \\
\hline 8 (South) & $\begin{array}{c}\text { Les Villas de Bel } \\
\text { Ombre } \\
\end{array}$ & Bel Ombre & 288 & $\begin{array}{c}\text { Existing Golf Course, beach } \\
\text { club } \\
\end{array}$ & 103.00 & 613-3201 & short distance from the sea & USD 554,196-2,380,000 \\
\hline 3 (South West) & $\begin{array}{c}\text { Belle Rivière } \\
\text { promotion Ltd } \\
\end{array}$ & Bel Ombre & 33 & $\begin{array}{c}150 \text { rooms Accor operated } \\
\text { hotel (Sofitel So) }\end{array}$ & 21.00 & $2592-4782$ & Ocean view & Euro $1,100,000-2,400,000$ \\
\hline 4 (South West) & $\begin{array}{c}\text { Dolphin Coast } \\
\text { Marina Estate Ltd } \\
\end{array}$ & $\begin{array}{c}\text { La Mivoie, } \\
\text { Riviere Noire }\end{array}$ & 113 & Marina & 14.47 & $135-2000$ & Ocean view & MUR $15,600,000-68,000,000$ \\
\hline 6 (Soub West) & $\begin{array}{c}\text { Matala Properties } \\
\text { Ltd (Soc. Ramdenee) }\end{array}$ & Rivière Noire & 70 & $\begin{array}{c}\text { Club House, a spa and a } \\
\text { restaurant }\end{array}$ & 19.00 & $777-5000$ & $\begin{array}{l}\text { short distance from the } \\
\text { sea }\end{array}$ & USD 500,000-2,098,000 \\
\hline 5 (North East) & $\begin{array}{c}\text { Haute Rive IRS Co } \\
\text { Ltd }\end{array}$ & Haute Rive & 169 & $\begin{array}{c}92 \text { apartments, } 23 \\
\text { penthouses, } 54 \text { duplexes; } 35 \\
\text { key luxury boutique hotels } \\
\text { with gym and spa and } \\
\text { wellness centre; }\end{array}$ & 12.84 & $110-306$ & Ocean view & MUR 15,300,000-36,000,000 \\
\hline
\end{tabular}

Source: Data obtained from Board of Investment (2014) 
Table 2: Determinants of Changes in Local Land Prices

Dependent Variable: Change in the price of local land

\begin{tabular}{lll}
\hline Variable & Coefficient & t-Statistic \\
\hline Intercept & $9.268468^{* * *}$ & 15.64336 \\
TOTAL_IRS_VALUE & $2.94 \mathrm{E}-09^{*}$ & 1.729603 \\
\hline R-squared & 0.047042 & \\
Adjusted R-squared & 0.026325 & \\
F-statistic & 2.270730 & \\
Prob(F-statistic) & 0.138675 & \\
\hline
\end{tabular}

Notes: Total panel observations: $48,{ }^{*}$ significant at $10 \%$ and $* * *$ significant at $1 \%$ 
Table 3: Determinants of Individual IRS/RES Plot Prices, Year Dummies Included

\begin{tabular}{|c|c|c|c|c|}
\hline Variable & Coefficient & t-Statistic & Coefficient & t-Statistic \\
\hline Intercept & $-1.48 \mathrm{E}+08 * * *$ & -3.054494 & $-1.28 \mathrm{E}+08 * * *$ & -3.430242 \\
\hline PLOT_SIZE & $28624.34 * * *$ & 6.810412 & $29227.56 * * *$ & 7.029432 \\
\hline OCEAN_VIEW & $33753851 *$ & 1.868701 & $32438422^{*}$ & 1.818541 \\
\hline LOCALPRICE & $12342.40 * * *$ & 3.004412 & $10496.12 * * *$ & 4.209599 \\
\hline REGION2 & 17165914 & 0.895097 & 21902016 & 1.235103 \\
\hline REGION3 & $-55271208 * * *$ & -3.024094 & $-57915913 * * *$ & -3.294175 \\
\hline REGION4 & $-77630265^{*}$ & -2.863084 & $-70532288 * * *$ & -3.274376 \\
\hline REGION5 & 16249531 & 0.671691 & 12802942 & 0.746526 \\
\hline REGION6 & $45724997^{*}$ & 1.651099 & 35859512 & 1.576062 \\
\hline REGION7 & $-66016126 * * *$ & -3.032251 & $-56086575 * * *$ & -3.186338 \\
\hline REGION8 & 18388083 & 0.899878 & 15569102 & 0.789593 \\
\hline D2006 & 15013085 & 0.871811 & - & - \\
\hline D2007 & -1293600 & -0.069024 & - & - \\
\hline D2008 & -1936861 & -0.094862 & - & - \\
\hline D2009 & -521753 & -0.022437 & - & - \\
\hline D2010 & -2119363 & -0.096313 & - & - \\
\hline D2011 & -11386943 & -0.488789 & - & - \\
\hline D2012 & 937139 & 0.037472 & - & - \\
\hline D2013 & -7587208 & -0.279347 & - & - \\
\hline Number of Obs. & 610 & & 610 & \\
\hline R-squared & 0.182984 & & 0.177172 & \\
\hline Adjusted R-squared & 0.158101 & & 0.163435 & \\
\hline F-statistic & 7.353577 & & 12.89768 & \\
\hline Prob(F-statistic) & 0.000000 & & 0.000000 & \\
\hline Durbin-Watson & 1.708 & & 1.704 & \\
\hline \multicolumn{5}{|l|}{ Breusch-Pagan-Godfrey } \\
\hline hetero F-test ( $p$-value) & $0.942(0.53)$ & & $1.073(0.38)$ & \\
\hline \multicolumn{5}{|c|}{ Jarque-Bera normality test } \\
\hline (p-value) & $403400(0.00)$ & & $417698(0.00)$ & \\
\hline
\end{tabular}

Notes: The regression presented in the left-hand panel includes year dummies whereas that in the right-hand panel does not. Dependent Variable: PRICE; ${ }^{*}{ }^{* *}$ and $* * *$ denotes significance at the $10 \%, 5 \%$ and $1 \%$ levels respectively. 
Figure 1: Evolution of the Real Estate and Construction Sectors (2005-2013) - Source (Statistics Mauritius)

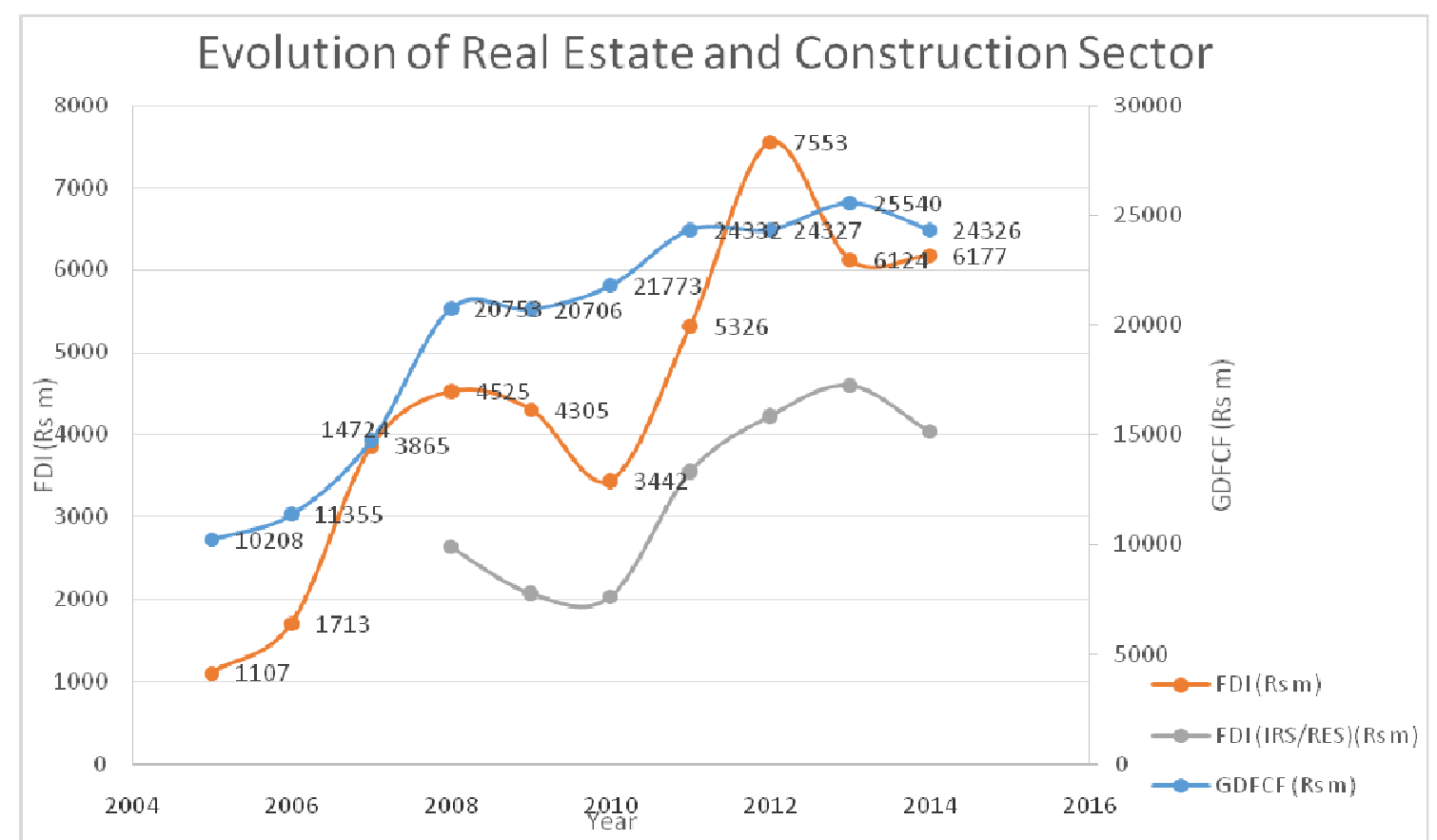

The blue line represents the GDFCF contribution of the Real sector (Rs million) while the red line represents the Real Estate Investment contribution (FDI) (Rs million)

Figure 2: Land Prices in Mauritius 2000-2013

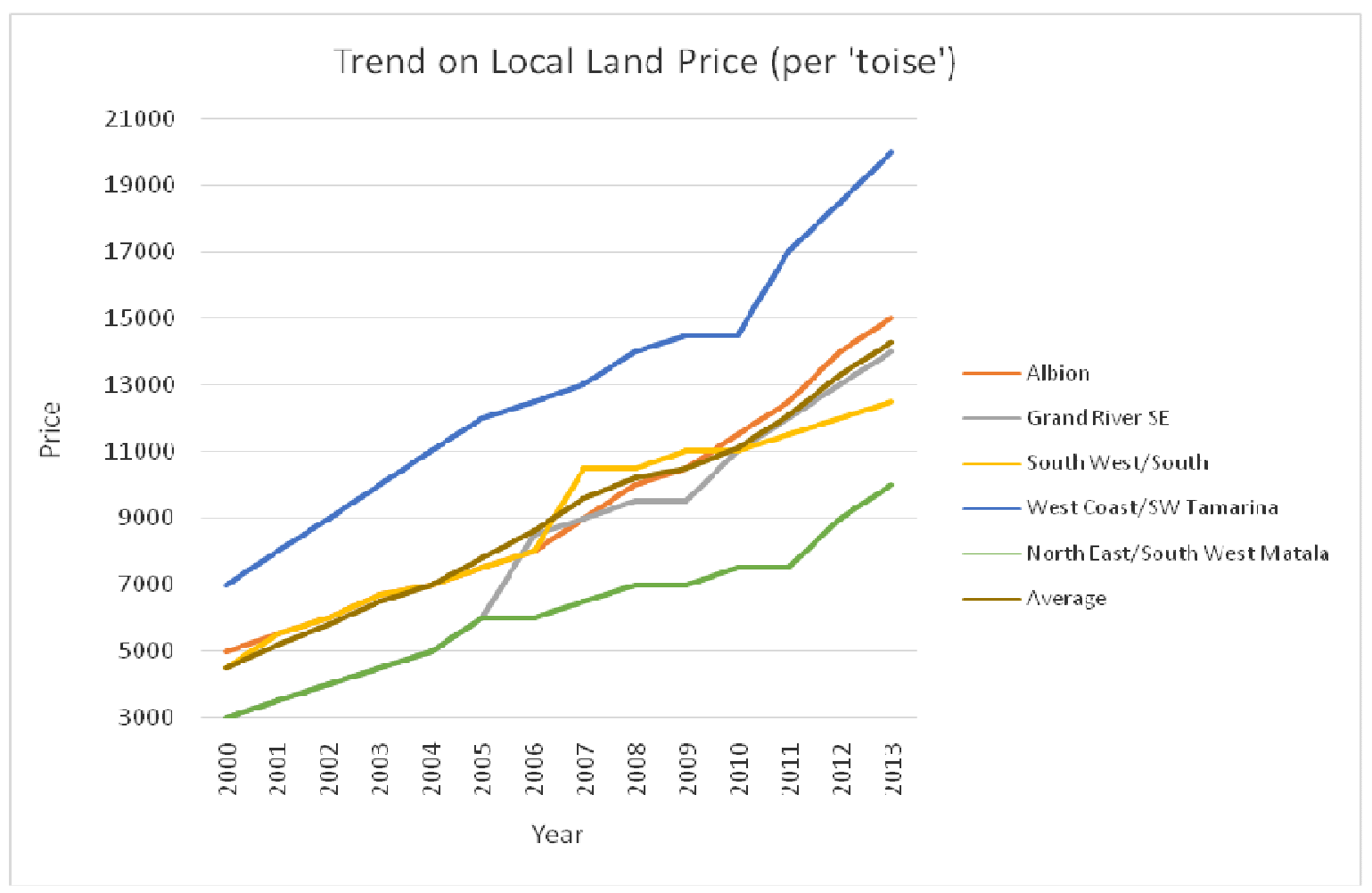

